\title{
Problem chłopski na łamach „Pamiętnika Historyczno-Politycznego" Piotra Świtkowskiego
}

\section{Wstęp}

Piotr Świtkowski (1744-1794), jezuita i wydawca, w swoim krótkim życiu wniósł ogromne zasługi jako redaktor, pomysłodawca wydawnictw ciągłych, ale też autor książek czy poradników poświęconych ważnym społecznie i gospodarczo zagadnieniom. Wiadomo, że był z założenia fizjokratą ${ }^{1}$. Sądził, że jedynie ziemia, a więc rolnictwo i górnictwo daje ,czysty zysk”. Dowiódł tego przede wszystkim na łamach swojego najbardziej znanego periodyku, czyli „Pamiętnika

\footnotetext{
1 Nie ma tutaj miejsca na szczegółowe wyliczenie najważniejszych twierdzeń fizjokratyzmu, a tym bardziej na prześledzenie przemian dej doktryny. Dokonywały się one zaś nie tylko pomiędzy Francoisem Quesnayem a jego spadkobiercami w osobie np. Ann de Turgota, ale zyskiwały też specyficzny charakter w poszczególnych krajach. Generalnie fizjokratyzm składał się z następujących komponentów: 1) uznanie rolnictwa i górnictwa za jedyne źródła „,czystego zysku”, 2) podział społeczeństwa na rolników, właścicieli i klasę jałową, 3) trójczęściową wolność jednostki, 4) własność jako podstawę dobrobytu, 5) gloryfikację cywilizacji, 6) prawo natury, 7) liberalizm ekonomiczny i niechęć do merkantylizmu, 8) ideę ,,jedynego podatku”, 9) akceptację silnej władzy monarchy, 10) nacisk kładziony na edukację i prawodawstwo. M. Blaszke, Obraz i naprawa Rzeczpospolitej w myśli społeczno- politycznej Baudeau i le Mercier de la Riviere, Warszawa 2000, s. 15-23; K. Gide, K. Rist, Historja doktryn ekonomicznych od fizjokratyzmu do czasów najnowszych, t. 1, Warszawa 1920, s. 1-20, 40-45; H. Olszewski, M. Zmierczak, Historia doktryn politycznych i prawnych, Poznań 1993, s. 162-164. Warto jeszcze za F. Quesnayem zdefiniować różnicę pomiędzy prawem natury a prawem pozytywnym. Jak pisał: „Prawo przyrodzone tym się różni od prawa pozytywnego, ustanowionego przez ludzi, że do poznania jego oczywistości dochodzi się samym rozumem, i że skutkiem tej oczywistości jest ono obowiązujące niezależnie od wszelkiego przymusu; gdzie przeciwnie, prawo pozytywne, ograniczone przepisami, obowiązuje mocą kary, grożącej za przekroczenie tego prawa, chociaż byśmy je znali tylko z prostej wzmianki, wyrażonej w ustawie”. F. Quesnay, Pisma wybrane, przeł. B. Pietkiewiczówna, Kraków 1928, s. 82.
} 
Historyczno- Politycznego"2. Osoba Piotra Świtkowskiego należy przy tym do przeciętnie znanych: nie jest anonimowa, ale część jego spuścizny wymaga przebadania i komentarza ${ }^{3}$. Interesujący wydaje się być stosunek najważniejszego z wydawanych przez księdza redaktora czasopism do chłopów ${ }^{4}$. W jakim kontekście ukazywał ich rolę w społeczeństwie „Pamiętnik”? Czy znajdowały się tam postulaty polityczne, czy też jedynie dbałość o cywilizacyjne wydźwigniecie chłopskich mieszkańców wsi ${ }^{5}$ ? Jakie aspekty gospodarowania należało poprawić? Wydaje się, że na te pytania pomoże odpowiedzieć analiza zamieszczanych w czasopiśmie artykułów.

\section{Życie i kariera Piotra Świtkowskiego}

W tym miejscu wypada zatrzymać się nad karierą samego Piotra Świtkowskiego. Zdaniem Andrzeja Grodka napisał on przynajmniej 21 artykułów ${ }^{6}$ wydźwięku

2 „Pamiętnik Historyczno-Polityczny przypadków, ustaw, osób, miejsc i pism wiek nasz szczególniej interesujących”, Warszawa 1982-1792 (później: „Pamiętnik Historyczno-Polityczno-Ekonomiczny"; dalej: PHP).

3 Często podobnego „odczytania na nowo” wymagają poglądy polskich fizjokratów jako takich. Jak pisał niemal sto lat temu Jan S. Lewiński: „System fizjokratyczny odkryty został dla nauki dopiero w XIX wieku. Przez długi czas widziano w nim jedynie doktrynę, według której rolnictwo jest jedynym źródłem bogactwa. Merkantylizm i fizjokratyzm- były to, według zdania historyków ekonomii, fałszywe systemy, a dopiero pojawienie się Bogactwa narodów A. Smitha było pierwszym krokiem w kierunku ukonstytuowania się ekonomii politycznej". J. A. Lewiński, Twórcy ekonomii politycznej, Lublin 1921, s. 22-23.

4 Według ustaleń Tadeusza Korzona chłopi w 1791 r. mogli liczyć nawet 6,4 mln osób. Dzielili się na pięć głównych kategorii: 1) wolnych chłopów-kmieci (ok. $1 \mathrm{mln}), 2)$ poddanych w ekonomiach król. $(0,195 \mathrm{mln}), 3)$ poddanych starostw król. $(0,84 \mathrm{mln}), 4)$ poddanych w dobrach duchownych $(0,86 \mathrm{mln}), 5)$ poddanych w dziedzicznych dobrać szlacheckich (3,55 mln). T. Korzon, Ludność Polski w roku 1791, [w:] Odrodzenie w upadku. Wybór pism historycznych, Warszawa 1975, s. 82-84. W kwestii podziałów religijnych: przeważali wierni Kościoła rzym.- kat. (3,5 mln) nad unitami (ok. 2,6 mln). A. Jezierski, C. Leszczyńska, Historia gospodarcza Polski, Warszawa 2003, s. 74. Warto zwrócić uwagę na zaproponowany przez Tomasza Wiślicza podział chłopów ze względu na kryterium językowe i na pracę Michała Kopczyńskiego, który wyodrębnił trzynaście grup ze względu na wykonywane zajęcia. T. Wiślicz, Naród chłopski? Społeczna, religijna i narodowa tożsamość chłopów we wczesno nowożytnej Polsce, [w:] Między barokiem a oświeceniem. Społeczeństwo stanowe, red. S. Achremczyk, S. Kiełbik, Olsztyn 2013, s. 55-56; M. Kopczyński, Studia nad rodzinq polska w Koronie w XVII- XVIII w., Warszawa 1998, s. 49.

5 Pewne wątpliwości budzi przejaskrawienie roli „kwestii włościańskiej” zwłaszcza w starszej literaturze, np.: „Wieś stanowiła centrum problemów społecznych osiemnastowiecznej Polski. Kwestia chłopska, szczególnie w schyłkowym okresie Rzeczypospolitej, zaprzątała umysły wielu osób. W przeciągu niespełna dziesięciu lat ukazało się ponad dwadzieścia broszur i kilka artykułów prasowych dotyczących problematyki kwestii włościańskiej”. J. Rosicka, Polskie spory o własność. Narodziny nowożytnej myśli ekonomicznej na ziemiach polskich (1765-1830), Kraków 1984, s. 31.

6 A. Grodek, Ks. Piotr Świtkowski, statysta polski końca XVIII w., „Rocznik Dziejów Społecznych i Gospodarczych" 1934, R. 3, s. 201-202 
ekonomicznym, jednak w tym przypadku istotny jest również jego wkład redaktorski. Urodził się w 1744 r. w Krakowie jako syn mieszczański ${ }^{7}$. Wiadomo, że posiadał dwoje rodzeństwa. Do Towarzystwa Jezusowego wstąpił w 1765 r. ${ }^{8}$ Nie był to już zakon jezuicki, z którego szydzić zwykli w swoich utworach oświeceniowi literaci. Wręcz przeciwnie: coraz śmielej czerpał pomysły z reform szkolnych wprowadzanych przez pijarów, wkrótce też zaczął z nimi rywalizować w nowych przedsięwzięciach. Nie przypadkiem właśnie z zakonu jezuickiego wyszło wielu późniejszych przedstawicieli i propagatorów polskiego oświecenia, choćby Grzegorz Piramowicz czy Franciszek Bohomolec.

Podobnie było ze Świtkowskim, który rozpoczął karierę od seminariów krakowskich, jednak lata 1765-1772 spędził na zdobywaniu dalszego wykształcenia w Poznaniu. Wkrótce został nauczycielem szkół średnich w tym mieście oraz w Łęczycy ${ }^{9}$. Lata 1772-1775 zamknął uzyskaniem tytułu profesorskiego po skończeniu studiów teologicznych. Pobyt w stolicy Wielkopolski zaowocował dla Świtkowskiego interesującymi znajomościami. Wydaje się, że jedną z najistotniejszych zawarł z Józefem Rogalińskim. Łącząc w sobie zapał do posługi kapłańskiej z uprawianiem matematyki i fizyki, kapłan ten odebrał gruntowne wykształcenie w uczelniach Rzymu i Paryża ${ }^{10}$. Być może to z jego inspiracji czy dzięki utrzymywanym przez Rogalińskiego kontaktom „Pamiętnik Historyczno- Polityczny” zawierał tak rozległy zakres materiału. Kasata zakonu jezuickiego (1773) zastała Świtkowskiego jako nauczyciela szkół średnich. Poprzestał on jednak na pobieraniu pensji w wysokości 200- 500 złotych rocznie i nie został nauczycielem w szkołach Komisji Edukacji Narodowej, co było wówczas alternatywą dla byłych jezuitów ${ }^{11}$.

Przez kolejnych dziesięć lat występuje w życiorysie byłego jezuity wiele niejasności. Bywał w Warszawie, nieco czasu spędził w majątku Kromlice niedaleko Kórnika, gdzie przebywał u Antoniego Zakrzewskiego ${ }^{12}$. Prawdopodobnie odbywał też wyjazdy zagraniczne. Drobiazgowy sposób, w jaki opisywał kraje niemieckie i Austrię, może sugerować, że udawał się właśnie tam. Przełomowa była dla niego znajomość z rodziną Sułkowskich i jej głową - Augustem, marszałkiem Rady Nieustającej i wojewodą ${ }^{13}$. Wrażenie na Świtkowskim wywarła Rydzyna Sułkowskich, gdzie jeszcze z XVII w. kultywowano tradycje dobrego gospodarowania: rozwój browarnictwa i rzemiosła, dbałość o wybrukowanie dróg

I. Łossowska, Piotr Świtkowski, [w:] Pisarze polskiego Oświecenia, red. T. Kostkiewiczowa, Z. Goliński, t. 2, Warszawa 1994, s. 305.

8 Ibidem.

9 Ibidem.

10 Ibidem, s. 305.

11 Ibidem, s. 305-306.

12 Ibidem, s. 305.

13 Ibidem, s. 306. 
i unowocześnienie produkcji ${ }^{14}$. Sam Świtkowski w 1782 r. zamieszkał w pałacu należącym do Sułkowskich, który znajdował się w Warszawie przy ul. Trębackiej ${ }^{15}$.

W tym miejscu warto pochylić się nad tym, czym faktycznie zasłynął Świtkowski, czyli ogromem jego prac redaktorskich. Pieniądze czerpał z pensji, o której zwiększenie ciągle u króla zabiegał, donacji, oraz od prenumeratorów dzieł. Warto zaznaczyć, że działalność ta trwała ledwie jedenaście lat (1782-93) i wymagała niemałej pracowitości od samego Świtkowskiego, który zatrudniał ludzi do pomocy, na stałe jednak pracował sam z jednym pomocnikiem. Nie licząc prób poetyckich, które mu się przypisuje ${ }^{16}$, Świtkowski zajmował się pracami dwojakiego typu. Były to: wydawnictwa pomyślane jako periodyki, oraz inne książki, zwykle mające przemycić na rodzimy grunt jakieś nowości gospodarskie czy techniczne.

Poza „Pamiętnikiem Historyczno-Politycznym”, do periodyków zaliczyć warto „Magazyn Warszawski” i „Wybór z Wiadomości Gospodarskich”. Pierwsze pismo zostało pomyślane jako rozszerzenie treści zawartych w PHP i wzbogacenie ich o treści zogniskowane na kulturze ${ }^{17}$. Drugie upowszechniało treści na temat nowych metod gospodarowania szerszej grupie czytelników. Wśród pojedynczych publikacji eksjezuity warto wymienić również Budowanie wiejskie z 1782 r. i Architekta wiejskiego; prace te zajmowały się zagadnieniami związanymi z poprawą zabudowy, doborem materiałów i miejsc pod budowę. Pod koniec życia Świtkowski ruszył z wydawaniem nowego pisma - „Zabawy Obywatelskie”, które wychodziło pomiędzy wrześniem 1792 a wrześniem $1793^{18}$. Dobrym podsumowaniem jego kariery wydają się być słowa napisane przez Irenę Łossowską: „Koleje losu i droga życiowa Świtkowskiego świadczą o dużych jego zdolnościach, energii i pracowitości. Ubogi i nikomu nie znany, potrafił w obcym sobie środowisku warszawskim zdobyć uznanie i popularność”"19.

\section{Diagnoza ekonomicznej roli chłopów w Rzeczypospolitej}

„Pamiętnik Historyczno-Polityczny” zasługuje na szczególną uwagę z kilku powodów. Przede wszystkim połowę jego objętości zajmował materiał zagraniczny, który czerpał z kilku zachodnich periodyków i publikacji ${ }^{20}$. Od samego

\footnotetext{
14 Stownik Geograficzny Królestwa Polskiego i innych Krajów Słowiańskich, t. X, Warszawa 1889, s. 85 .

15 I. Łossowska, op. cit. s. 306.

16 Ibidem, s.319.

17 J. Łojek, Historia prasy polskiej, t. 1, Warszawa 1976, s. 51.

18 I. Lossowska, op. cit. s. 319

19 Ibidem, s. 318.

20 Z czasopism francuskich należy wymienić „,Journal Encyclopedique”, „Mercure de France” i „Journal de Paris”. I. Łossowska, op. cit., s. 311. Dzięki niezwykle owocnym badaniom Doroty
} 
początku miały na jego łamach ukazywać się artykuły dotyczące handlu czy nowin ekonomicznych ${ }^{21}$. Czytelnicy mogli również otrzymać informacje o dalekiej Syrii, banku londyńskim czy panowaniu Fryderyka II w Prusach. Z drugiej strony- zaznajamiali się z nazwiskami Rousseau, Woltera, Linneusza czy Franklina ${ }^{22}$. Istotną rolę odgrywały listy do redakcji, jak się wydaje, po większej części autentyczne. Miesięcznik, wydawany jednak w formie kwartalnej broszury, zmieniał nieznacznie swoją nazwę i zdobył licznych abonentów ${ }^{23}$; zyskał też stosunkowo dużą poczytność docierając do wielu miast w kraju ${ }^{24}$. Pewne problemy przeżywał również z powodu cenzury, jednak udało się go wydawać aż do czasów targowickich, kiedy to został zamknięty ${ }^{25}$. Przechodząc do analizy treści zawartych w „Pamiętniku Historyczno-Politycznym” należy przyjrzeć się sposobowi, w jaki periodyk Świtkowskiego starał się odmalować sytuację stanu chłopskiego w Rzeczypospolitej w perspektywie ekonomicznej. Tę ostatnią rozpatrywać należy jakby w dwóch płaszczyznach: 1) z perspektywy państwa i systemu ekonomicznego, 2) z punktu widzenia chłopów i ich codziennych wyborów ekonomicznych.

Siodorowicz więcej możemy powiedziec o znajomości prasy niemieckiej przez Piotra Świtkowskiego i jej wykorzystaniu na łamach periodyku. Autorka wykorzystała m.in. bazy bibliograficzne stworzone na niemieckich uniwersytetach, które w połączeniu z kwerendą archiwalną i dzięki zastosowaniu metody bibliograficznej dały ciekawy obraz. Z czasopism niemieckich czerpał redaktor nie tylko informacje o tamtejszych krajach, ale też nowinki rolnicze i gospodarskie; nawet Portret generała Washingtona został przedrukowany z czasopisma „Historisches Portefeuille zur Kenntnis der gegenwärtigen und vergangenen Zeit" (łącznie 40 przedrukowanych tekstów). Kilkanaście artykułów zaczerpnął też ze „Stats-Anzeigen” wydawanego na Uniwersytecie w Getyndze. Poza tym Świtkowski przedrukowywał teksty z „Berlinische Monatsschrift”, „Der Teusche Merkur”, „Ephemeriden der Menschheit”; zamieścił też fragmenty pamiętników Fryderyka II. Generalnie można się zgodzić z opinią autorki, że: „Udział czasopism Piotra Świtkowskiego w przepływie różnorodnych informacji z Niemiec do Polski jest ogromny. Na łamach redagowanych przez siebie periodyków Świtkowski publikował zarówno przejęte z niemieckich źródeł teksty polityczne, społeczne i gospodarcze, jak i rozprawy naukowe". Zob. D. Sidorowicz, Udział czasopism Piotra Świtkowskiego w niemiecko- polskim transferze kulturowym doby oświecenia w ujęciu bibliograficznym, [w:] Bibliologia. Problemy badawcze nauk humanistycznych, red. D. Kuźmina, Warszawa 2007, s. 235, 237, 239; eadem, „Pamiętnik Historyczno-Polityczny” (1782-1792) w świetle źródet, [w:] Krajobrazy przeszłości. Księga ofiarowana doktorowi Adolfowi Juzwence w siedemdziesiąta rocznicę urodzin, red. M. Dworsatschek, Wrocław 2009, s. 242-243.

21 Danuta Hombek przywołała m.in. mało znany prospekt czasopisma z 28 września 1782 podpisany przez wydawcę Michała Grölla, gdzie zapowiadano w stałych działach poruszanie kwestii ekonomicznych czy dotyczących źródeł potęgi poszczególnych krajów. D. Hombek, Prasa i czasopisma polskie XVIII wieku w perspektywie bibliograficznej, Kraków 2001, s. 195.

22 I. Łossowska, op. cit., s. 312.

23 Więcej o dystrybucji i abonentach periodyku można przeczytać w pracy Danuty Hombek. Zob.

D. Hombek, op. cit., s. 195- 198.

24 Ibidem, s. 200.

25 Stało się tak za sprawą rozporządzenia targowickiej Generalności z 7 IX 1792 r. I. Łossowska, op. cit., s. 317. 
Jeśli występowała niechęć do zaliczenia chłopów w skład narodu politycznego, coraz bardziej uświadamiano sobie ich rolę w systemie gospodarczym, ukazywanym za pomocą metafory ludzkiego ciała ${ }^{26}$. Upatrywano w Rzeczypospolitej kraju rolniczego, gdzie praca chłopska stanowiła istotny czynnik produkcji ${ }^{27}$. Różne były na łamach „Pamiętnika” interpretacje tego faktu - zwłaszcza, że jak podkreślił Ryszard Bartkowiak - fizjokratyzm wniósł pokaźny wkład w narodziny i rozwój makroekonomii ${ }^{28}$. W numerze z września 1784 r. czytamy: „Ziemia jest źródłem z którego wszystko płynie, czego tylko do życia ludzkiego potrzeba" ${ }^{29}$. Podobnie pisał sam Świtkowski, zdradzając swoje fizjokratyczne zapatrywania: „Jak wielki jest mój rolnictwa szacunek, wiedzą czytelnicy „Pamiętnika”, jak i to, że go mam za najobfitsze źródło pomyślności kraju mojego" ${ }^{30}$. W artykule Dawny handel Polski czytamy, że królujący w dawnych wiekach handel zbożem upadł w wyniku zbytku szlachty, której nie zależało na propagowaniu manufaktur i fabryk ${ }^{31}$. Mamy

26 PHP, X 1788, s. 878- 879. Jak pisał W. Stanek: „Przeszczepienie metody nauk przyrodniczych na grunt nauki ekonomicznej okazało się wysoce płodne w tworzeniu jednolitego obrazu gospodarstwa społecznego. Nomotetyczny charakter dociekań ekonomicznych prowadził do wykrywania prawidłowości rządzących całokształtem zjawisk społ.-gosp.”. W. Stankiewicz, Fizjokratyzm, Warszawa 1982, s. 11.

27 W. Stankiewicz zauważył, że właśnie fizjokraci w sposób bardzo poważny zajęli się analizą procesu produkcyjnego. Zob. ibidem, s. 3.

28 R. Bartkowiak, Historia myśli ekonomicznej, Warszawa 2003, s. 33. Warto nadmienić, że we Francji zainteresowanie ziemią miało charakter związany z krachem kolbertyzmu i aferami finansowymi z początku stulecia (np. afera Johna Lawa). W ziemi upatrywano pewniejszego miejsca dla lokaty kapitału. W. Stankiewicz, op. cit., s. 5. W inny sposób fenomen fizjokratyzmu widzieli Harry Landreth i David C. Colander: ,prace szkoły fizjokratów wyrażają zasługującą na uwagę spójność poglądów. Złożyły się na to trzy przyczyny: (1) fizjokratyzm rozwinął się wyłącznie we Francji; (2) idee fizjokratów były prezentowane przez stosunkowo krótki czas 1750-1780, (3) fizjokraci mieli uznanego lidera intelektualnego Francois Quesnaya”. H. Landreth, D. C. Colander, Historia myśli ekonomicznej, Warszawa 2005, s. 71.

29 PHP, IX 1784, s. 809. Symptomatyczne, że w Polsce częściej broniono chłopa i jego doli, niż działo się to we Francji: „U Quesnaya gospodarka chłopska nie ma znaczenia gospodarczego, ponieważ chłop wszystko co produkuje, sam zjada, nie wytwarza bowiem produktu czystego. Produkcyjna jest tylko wielka uprawa, ponieważ czynione czynione tu nakłady dają produkt czysty, przewyższający nakłady”. E. Lipiński, Historia polskiej myśli społeczno- ekonomicznej do końca XVIII wieku, Wrocław 1975, s. 335.

$30 \quad$ PHP, IV 1784, s. 364

31 Ibidem, II 1784, s. 156. Z innej strony trzeba jednak podkreślić, że był to pewien negatywny obraz szlachty, którym posługiwano się w celu ukazania nieracjonalnego i „moralnie szkodliwego” charakteru takich działań, Przeciwieństwem marnotrawstwa i konserwatyzmu w gospodarowaniu nie była afirmacja niższych warstw szlacheckich. Myliła się więc chyba Janina Rosicka usiłując w swojej pracy klarownie wydzielić trzy tradycję postaw względem własności: sarmacką, oświeceniową i romantyczną. W rzeczywistości się one przenikały i występowały w wielu różnych wariantach. J. Rosicka, Polskie spory..., s. 31 i inne. Sami fizjokraci uważali wolność bez własności za „wolność szaleńca”. M. Indan-Pykno, Fizjokratyzm oczyma przedstawicieli polskiej myśli polityczno- prawnej, „Annales UMCS” 2011, nr 2, s. 119. 
tutaj powiązanie rolnictwa z postulowaną przez fizjokratów wolnością handlu. Znajdujemy wręcz określenia, że rozpoczyna się „wiek handlowy”32, jak również, że „nie chleb, ale sprzedaż jego czyni bogactwo kraju”33.

W Polsce końca XVIII w. należało nie tylko zadbać o poprawę efektywności rolnictwa i o chłopów, ale też zapewnić zbyt ziemiopłodów ${ }^{34}$. Autor artykułu z kwietnia 1783 r. widział tutaj dwie przeszkody: niekorzystne traktaty handlowe z mocarstwami sąsiednimi, szczególnie z Prusami, które od dawna „psuły” polską monetę, oraz fakt, że rolnictwo zrobiło znaczne postępy również w innych krajach $^{35}$. Ostatni argument okazał się nie być trafny z uwagi na nagły przyrost ludności, skutkujący zapotrzebowaniem na żywność przede wszystkim w Wielkiej Brytanii. Populacjonizm, choć nie nadawano mu tego znaczenia, jakie później uzyskał u Thomasa Malthusa ${ }^{36}$, odgrywał znaczną i w przeciwieństwie do ujęcia reprezentowanego przez anglikańskiego duchownego - pozytywną rolę. Zaznaczano przy tym, że dla celów państwowych konieczne jest przeprowadzenie powszechnego spisu ludności ${ }^{37}$.

Mimo deklaracji, że „dobro powszechne jakiegoś kraju zasadza się na pomyślności wszystkich jego mieszkańców”38, warto przychylić się do opinii Janiny Rosickiej, iż fizjokratyzm miał zwiększyć efektywność folwarcznej gospodarki i zapewnić większe wpływy podatkowe ${ }^{39}$. Istotna była tutaj kwestia ,jedynego podatku"40. Różnie odnoszono się do kwestii zasobności szlacheckiego kraju. Dużą

\footnotetext{
32 Jak pisano: „Rolnictwo i handel słusznie w tym czasie są najprzedniejszym celem wielkich w rządzeniu krajami obrotów. Chociażby nowe fizjokratyczne systema, czyli umiejętność wybierania podatków z czystego gruntowego dorobku, nie odkryła nam była tyle ważnych wiadomości, to sama uwaga którą na rolnictwo wznieciła, byłaby już bardzo wielkiej wagi”. PHP, I 1783, s. 20.

33 Ibidem, IV 1783, s. 390

34 Jedną z wielkich zasług fizjokratów było podkreślenie wewnętrznych współzależności pomiędzy sektorami gospodarki. Służyła temu choćby słynna „Tablica ekonomiczna” opracowana przez Quesnaya, która stanowiła uproszczony model ekonomiczny, zawierający współzależności pomiędzy sektorami makroekonomicznymi. Zob. H. Landreth, D. C. Colander, op. cit., s. 72- 75.

35 PHP, IV 1783, s. 390

36 Zob. T. Malthus, Prawo ludności, Warszawa 2003.

37 Podobnie było odnośnie oszacowania liczby bydła żyjącego na terenie kraju: PHP III 1783, s. 390. Na marginesie trzeba dodać, że pierwszy taki spis miał miejsce w roku 1789, był stosunkowo niedokładny i miał charakter podatkowo-wojskowy.

38 PHP, IV 1783, s. 406- 407

39 J. Rosicka, Fizjokratyzm w Polsce [...] Physiocracy Yestrday and Today, red. J. Rosicka, Kraków 1996, s. 158.

40 Za Januszem Górskim warto ją wyłożyć następująco: „Ponieważ tylko w rolnictwie powstaje produkt czysty, powinien istnieć jeden podatek, pobierany bezpośrednio z tego produktu. (...) Podatek powinni więc płacić jedynie właściciele ziemscy, ponieważ oni (...) otrzymują w ostatecznym efekcie cały wytworzony produkt czysty". J. Górski, Zarys historii ekonomii politycznej, Warszawa 1982, s. 92- 93.
} 
rolę odegrały artykuły polemiczne, które (najprawdopodobniej ${ }^{41}$ ) przesyłano do redakcji. W Liście pewnego obywatela (...) względem ekonomii krajowej czytamy $o$ produktach krajowych, iż ,kontent Polak, gdy je jako tako in crudo przepchnąć może"42. Dalej mamy do czynienia z kolejnym zarzutem względem struktury produktów eksportowanych: „Znam ja, że rolnictwo jest źródłem bogactw, lecz nie widzę jakby samo zboże uszczęśliwiało" ${ }^{43}$. Dodatkowo jako problem postrzegano fakt, że wywozimy kilka tylko rodzajów produktów, importując znacznie bogatszy ich wybór ${ }^{44}$. Właściwą reakcją na tego rodzaju niekorzystne relacje miała być rodzima modyfikacja idei fizjokratycznych i zachęcanie do zakładania fabryk (czy raczej manufaktur), przystosowanych do polskiej specyfiki, oraz zatrzymanie „próżniaczych rąk”, czyli poskromienie konsumpcji towarów importowanych, gdy zachodzi taka koniecznośćc5.

Autorzy wymienionych myśli nie sprzeciwiali się wolności handlu; byli raczej zdania, że aby był on zyskowny - musi uzyskać zróżnicowaną strukturę i konkurencyjność. Dużą wagę przywiązywano przy tym do „cyrkulacji” pieniądza. Jak pisano: „owa dusza krajów wstrzymana i zatamowana byłaby, gdyby nie szły także na zakupowanie rzeczy obcych a tylko w szkatułach panujących nieużyteczne leżały" ${ }^{46}$. Nad to ostatnie preferowano zaciąganie długów - byle wewnątrz kraju. Całość kończyła wizja swego rodzaju fizjokratycznej pomyślności opartej na ,jedynym” podatku i pracy chłopa, które miały być zaczątkiem sukcesu także i Rzeczpospolitej: ,na koniec te tylko kraje zyskają, które wiele czystego zarodku z gruntów mieć będą. Tu to triumf będzie tych, którzy wszystkie podatki na grunta nakładać raczą. Ojczyzna także nasza jak na ów czas szczęśliwszą się od onych dziś złotem i srebrem zamożnych krajów okaże!" ${ }^{47}$

Przechodząc do położenia samych chłopów wypada zgodzić się z J. Rosicką, że fizjokratyzm: „Z jednej strony nie zaprzeczał wartościom sarmackim, z drugiej pozwalał na ich nowe odczytanie" ${ }^{\text {"48 }}$. Nowe konteksty, które nadane zostały przez tę doktrynę sarmatyzmowi ${ }^{49}$, nie mogą być jednak pojmowane jako mało efektywny

\footnotetext{
${ }^{41}$ W pewnych przypadkach trudno jest wnioskować czy była to realna polemika z tekstem opublikowanym wcześniej w „Pamiętniku”, czy też rodzaj gry redaktorów, chcących zainicjować pewną polemikę wokół istotnych spraw.

42 PHP, IV 1783, s. 389

43 Ibidem, III 1783, s. 390

44 Ibidem, IV 1783, s. 395

45 Ibidem, IV 1783, s. 396

46 Ibidem, I 1783, s. 16

47 Ibidem, I 1783, s. 18

48 J. Rosicka, Fizjokratyzm w Polsce..., s. 158.

49 Bardzo twórczo podszedł do problemu John K. Galbraith, pisząc o francuskich elitach rządzących i wytworzeniu przez nie ideologii, która racjonalnie uzasadniała ich panowanie. Jak pisał: „Jednak interesy ziemiaństwa we Francji były pod pewnym względem czymś wyjątkowym. Rzadko
} 
wstęp do radykalnych reform, jak chciała tego I. Homola- Dzikowska ${ }^{50}$. Przyświecał im typowy dla oświecenia utylitaryzm, który nie przeszkadzał patrzeć na chłopa jako na kogoś gorszego nie tylko od szlachcica, ale i mieszczanina ${ }^{51}$. Z drugiej jednak strony - kazał nadać mu tyle wolności, prawa do użytkowania czy na tyle dbać o jego interesy, o ile służyło to ogólnemu dobrobytowi.

Nie mogą więc dziwić narzekania dowodzące, że ,z tym wszystkim od wieków ziemię oddano i poruczono chłopom nierozumnym, rady sobie dać nieumiejącym i wszystko po bydlęcemu robiącym" ${ }^{52}$. Podobne opinie wobec chłopów korespondowały chyba tylko z niechęcią wobec Żydów, o których pisano, że są , ,ciemni i niezwyczajni do dobrej pracy" ${ }^{53}$. Nie był to jednak przykład jakiegoś programowego antysemityzmu: przyznawano, że należy ich edukować, tym zaś, którzy zechcą porzucić lichwę i handel dla rolnictwa - nadać nawet prawa ${ }^{54}$.

Nie tylko do samych chłopów miano pretensję jeśli chodzi o stan gospodarowania na polskiej wsi. Jak zauważano: „Panowie jak o to się starają bardzo, żeby z dóbr swych mnogich, wzięli jak największą arędę, tak o resztę wcale nie dbają.

się w historii zdarzało, żeby tego rodzaju społeczność stworzyła przekonujące filozoficznie uzasadnienie swoich przywilejów". Czy aby interesy polskiej magnaterii- arystokracji nie były podobnego rodzaju? Czy nowinki takie, jak fizjokratyzm, ale też tzw. „oświecenie chrześcijańskie” nie nadawały się idealnie do „oświecania” sarmatyzmu i nie łączyły z procesami, który trwały w Rzeczpospolitej przynajmniej od czasów Jana III Sobieskiego? Rzecz wymaga rozważenia. J. K. Galbraith, Ekonomia w perspektywie. Krytyka historyczna, Warszawa 1992, s. 59. Zob. też: M. Karpowicz, Sztuka oświeconego sarmatyzmu, Warszawa 1986; Mark O’Connor, Oświecenie katolickie i Marcin Poczobut SI [w:] Jezuici a kultura polska, red. L. Grzebień, S. Obirek, Kraków 1993, s. 41- 51.

50 I. Homola-Dzikowska, „Pamiętnik Historyczno-Polityczny” Piotra Świtkowskiego 1782-92, Kraków 1960. s. 41 i inne.

51 Chłopi byli w doktrynie fizjokratycznej istotni, ale jako siła robocza o którą należy dbać. Ważniejszy od nich był kapitał, którego wymagały wszelkie rolnicze przedsięwzięcia. Jak celnie zauważył W. Stanek: „Aby uzyskać czysty produkt, należy zainwestować przedtem kapitał potrzebny do przeprowadzenia melioracji, wprowadzenia płodozmianu, stosowania nawożenia i maszyn rolniczych. We Francji rolnictwo upada właśnie dlatego, że bogacze - posiadający wolne kapitały - nie inwestują w rolnictwo, a chłopi i drobni dzierżawcy nie mają potrzebnych kapitałów". W. Stanek, Fizjokratyzm..., s. 13-14. Nawet teoretyczne rozważania na temat upowszechniania własności w duchu egalitarnym budziły protest fizjokratów, którzy wierzyli, że tamuje to handel. Jak pisał Ann de Turgot: Przypuśćmy, że mieszkańcy kraju dzielą grunta tak, aby każdy otrzymał obszar dostateczny do swego wyżywienia, ale nic więcej. Wynikłaby stąd powszechna równość, ale nikt by nie chciał pracować dla drugich. Brakło by także środków na opłacenie obcej pracy, gdyż jednostka posiadając tylko tyle gruntu, aby się przeżywić mogła, spożywałaby wszystkie swe plony nie posiadając żadnego nadmiaru, który dałby się wymienić za pracę innych ludzi. A. Turgot, O tworzeniu i podziale bogactw, Kraków 1919, s. 14.

52 PHP, IX 1784, s. 810

53 W innym miejscu czytamy też: „Między innymi plagami kraj nasz uciskającymi (...) liczyć słusznie można tak wiele biednego, a samym prawie szacherstwem bawiącego się w Polszcze żydostwa". Ibidem, V 1785, s. 415; ibidem, IV 1785, s. 319.

54 Ibidem, V 1785, s. 418. 
Szlachta, mniej majętni duchowni, krzątają się prawda bardziej około gospodarstw, ale uprzedzenie dopuściż wielu spojrzeć na wychodzące pisma gospodarskie?"55. W zasadzie zgodnie podkreślano, że mankamentem wiejskiego życia i gospodarowania był wspomniany konserwatyzm, jeśli chodzi o metody, dokuczliwy brak kapitału, oraz niski poziom cywilizacyjny: „Wszystkim się już polakom przykrzy trwający dotąd nierząd, wstyd patrzeć na ich wsie, do mieszkań bydlęcych podobne, na miasta puste (...) na kraj cały próżniakami i włóczęgami napełniony"56. Rolnictwo, określane jako „matka plemienia ludzkiego” z którego „powstały prawa, które podtrzymują narody" ${ }^{57}$, nie otrzymywało właściwego wsparcia ze strony szlachty i ustawodawstwa. Uświadamiano sobie coraz częściej: „,niech nawet i rolnik, ten , mówmy prawdę, najużyteczniejszy członek społeczności będzie wolny" 58 .

Nie było tu oczywiście mowy o jakichś radykalnych reformach, ale raczej pracy oświeconych panów nad zamieszkującymi ich dobra chłopami- rozumianej tutaj nie tylko jako polepszenie warunków życia, ale i prowadzące do tego zachęty czy przykłady. Autor artykułu podkreślał więc, że „między tym gminem ciemnych, a wiele o sobie trzymających gospodarzy znajdują się światłe osoby" ${ }^{59}$. Pańszczyzna i ucisk chłopa były pojmowane nie tyle jako niehumanitarne, bo kwestie te w dużej mierze przejaskrawiła historiografia i myśl marksistowska ${ }^{60}$, co nieekonomiczne i sprzeczne z prawem naturalnym ${ }^{61}$. Tym bardziej, że chłop od którego zależała produkcja, narażony był na wiele trudności bytowych: ,powietrze lada jakie, niestabilność czasów, burze i wiatry sprawują, że się rolnik na nadziei swojej nie raz pomylił" ${ }^{2}$. Konieczność zapewnienia chłopom takich kwestii, jak kapitał na

\footnotetext{
55 Ibidem, III 1786, s. 281.

56 Ibidem, VII 1787, s. 617. Wydaje się, że cytat oddaje niektóre procesy zachodzące na polskiej wsi w toku XVIII stulecia, choćby: zmniejszenie liczby gospodarstw szlachty drobnej i zagrodowej czy wzrost liczby tzw. „ludzi luźnych”. Zarys historii gospodarstwa wiejskiego w Polsce, red. J. Leskiewicz, t. 2, Warszawa 1964, s. 91- 93, 103.

57 PHP, VII 1787, s. 619.

$58 \quad$ Ibidem, IV 1791, s. 371.

59 Ibidem,, III 1786, s. 281.

60 Zaważyła ona na bardzo negatywnym widzeniu epoki staropolskiej, zwłaszcza zaś czasów saskich jako czasu ,ucisku klasowego" I nieudanej walki o emancypację społeczną chłopów. Jest to jednak myślenie nazbyt doktrynalne i uproszczone.

${ }^{61}$ We Francji dobrze ujmował to Ann de Turgot, który bardzo wyraźnie zestawiał dolę robotnika i rolnika. Pierwszy z nich opisywany był jako ten, kto „posiada li tylko ręce i umiejętność ich używania, ma jedynie możność sprzedawania swojej pracy. Sprzedaje ją drożej lub taniej, która to cena nie zależy od niego samego. Wynika ona z umowy zawartej z zarobkodawcą". Inaczej wypowiadał się Turgot o rolnikach: „Położenie rolnika jest zupełnie inne. Ziemia uniezależnia go od każdego innego człowieka i od wszelkiej umowy i opłaca bezpośrednio cenę jego pracy. Natura nie targuje się z nim i nie zmusza go do zadowolenia się tylko niezbędnie potrzebną kwotą". A. Turgot, op. cit., s. $16-17$.
}

62 PHP, VII 1787, s. 623. 
urozmaicenie upraw, poprawa zabudowy, dróg a nawet umożliwienie im opieki lekarskiej, kazał myśleć o kwestiach rolniczych w sposób wieloaspektowy. Pojawiło się i upowszechniło przekonanie, że ,rolnictwo jest nauką daleko rozciągającą się, ściśle z fizyką i historią naturalną złączone" ${ }^{63}$, co spowodowało zainteresowanie analizą urodzajności gleb pod uprawę.

\section{Obce inspiracje}

Przekonanie o tym, że w Rzeczypospolitej istniało fizjokratyczne gospodarowanie jeszcze przed właściwym sformułowaniem doktryny ${ }^{64}$, trudno jest wspó1cześnie obronić. Trzeba stwierdzić raczej, że Rzeczpospolita nadawała się na „eksperyment fizjokratyczny”; pewne ideały związane z tą doktryną przetrwały zresztą krach państwa i były kontynuowane nie tylko w okresie bezpośrednio po rozbiorach, ale też w Księstwie Warszawskim, a nawet Królestwie Polskim ${ }^{65}$. Tym bardziej istotne jest to, jakimi reformami czy pomysłami kierował się Świtkowski dobierając czy pisząc artykuły do swojego periodyku. Stwierdzenie skąd zostały one zaczerpnięte i kto jest autorem bywa czasem trudne, dlatego też więcej miejsca zostanie poświęcone samym wypowiedziom na temat rolnictwa i chłopów. Te zaś były formułowane przy trzech głównych okazjach: 1) prezentacji teoretycznych programów ekonomicznych (,maxymy ekonomiczne Francois’a Quesnaya”"66), 2) analizy dorobku innych państw $\left.{ }^{67}, 3\right)$ jako element opowieści o dokonaniach władców i sławnych ludzi.

Pewnym pomysłem na kodyfikację prawideł nowego gospodarowania i upowszechnienie ich z dzieł obcych stały się Maxymy kraju rolniczego, publikowane w „Pamiętniku” od sierpnia 1787 r. ${ }^{68}$ Świtkowski skopiował je z pism Franciszka Quesnaya - nie wymieniając jednak nazwiska autora ${ }^{69}$. Pierwsza z nich, skłaniająca

\footnotetext{
63 Ibidem, III 1786, s. 283.

64 M. Blaszke, op. cit., s. 35.

65 Zob. M. Oczapowski, J, Bieniarzówna, Pokłosie fizjokratyzmu, [w:] Physiocracy ..., s. 207- 217.

66 Nie ma tutaj miejsca na przedstawianie życiorysu Francoisa Quesnaya (1694- 1774); należy za to wskazać kilka pozycji w języku polskim i francuskim, które pozwolą zorientować się w kolejach życia tego lekarza, myśliciela i ekonomisty. Wśród polskojęzycznych prac warto wymienić: Z. Pietkiewicz, Wstęp [w:] F. Quesnay, op. cit.; J. Zagórski, Ekonomia Franciszka Quesnaya, Warszawa 1963. Z prac francuskich warto przywołać: G. Weulersse, Les Physiocrates, Paris 1931; G. Sechelle, Le docteur Quesny, Paris 1907; Y. Guyot, Quesnay e de la physiocratie, Paris 1897.

${ }_{67}$ Trzeba tutaj dodać, że fizjokratyzm często wędrował z Francji do innych państw europejskich podobnymi kanałami, co do Rzeczpospolitej. Przykładem był choćby Victor de Mirabeau, który zadbał o przesłanie pism Quesnaya do Józefa II, Leopolda Toskańskiego czy Gustawa III Szwedzkiego, ale miał też kontakt z Joachimem Chreptowiczem. K. Opałek, Prawo naturalne u polskich fizjokratów, Warszawa 1953, s. 16.
}

68 PHP, VIII 1787, s. 698.

69 Zob. F. Quesnay, op. cit., s. 119- 156. 
się ku jedynowładztwu czy władzy silnej, zdradza, że raczej było to swoiste resume z pomysłów zagranicznych, niż program dla Rzeczypospolitej. Jak czytamy: „Systema równowartości sił politycznych, podłóg którego władza rządzona być powinna tylko w równoważności z potęgą prywatnych, zasadza się na szkodliwym błędzie i wychodzi nie na co innego, jak tylko na niezgodę Panów a uciemiężenie ubogich"70. Pozornie dotycząc polityki, cytat ten zdradza fizjokratyczną dbałość o konsensus społeczny - tylko droga spokojnego, ale trwałego wzrostu produkcji i rozwoju może przynieść zysk wszystkim stanom społecznym. Naród musi być „uświadomiony o porządku naturalnym”'71. Można to odczytywać nie tylko jako zapoznawanie szlacheckich właścicieli z fizjokratyzmem, ale też jako pomaganie gospodarzom w dostosowaniu prac rolniczych do kalendarza przyrodniczego, o czym mogą świadczyć ambicje pomniejszych wydawnictw czy kalendarzy, przeznaczonych dla chłopów np. przez ks. Pawła Brzostowskiego czy samego Świtkowskiego. Poza zapewnieniem, że tylko ziemia rodzi właściwy zysk, warto podkreślić szacunek fizjokratów dla własności - także chłopi powinni mieć pewność co do dzierżawionych przez nich gruntów, inaczej nie będą chcieli inwestować w nie środków i własnej pracy ${ }^{72}$.

Istotna była także konstrukcja jedynego podatku, który „powinien on być wybierany z czystego dóbr dochodu ${ }^{73}$, a nie z zapłaty za robotę ludzką, ani też z żywności lub rzeczy jakich (...); nie może być on też «rabunkiem»"74. Takie podejście do zagadnień fiskalnych zdaje się zbliżać poglądy fizjokratów do liberalizmu ekonomicznego, czemu często ulegali polscy historycy myśli ekonomicznej, jednak pamiętać należy, że posiadał też cechy odrębne i specyficzne. Podatek ten był poza tym dzielony na trzy części: 18\% dla właścicieli dóbr, 12\% dla państwa i 70\% dla chłopów.

Warto również przywołać VI i VII z proponowanych myśli Quesnaya. Pierwsza zalecała, że ,wydatki rolnicze muszą być dostateczne”, druga chciała, by „,suma dochodów rozchodziła się jak najbardziej po kraju"75. Chodziło tutaj oczywiście o zapewnienie nakładów na funkcjonowanie i modernizację gospodarstwa, oraz zapewnienie ,cyrkulacji” pieniądza w handlu wewnętrznym - „Trzeba tu uważać, że pola choć najżyźniejsze, kiedy nie mam co łożyć na ich dostateczną uprawę, nie przyniosłyby najmniejszego pożytku; a przeto wielka to jest prawda, że mizerny stan rolnictwa i pospólstwa w jakim kraju trzeba przypisać nie tak niedbalstwu

\footnotetext{
70 PHP, VIII 1787, s. 698. Warto wskazać, że także u A. Turgota poddaństwo było uznawane za system wyjątkowo prymitywny, stanowiący kolejną fazę po niewolnictwie. A. Turgot, op. cit., s. 22.

71 PHP, VIII 1787, s. 701.

72 Ibidem, VIII 1787, s. 702.

73 Ibidem, VIII 1787, s. 703.

74 Ibidem.

75 Ibidem, IX 1787, s. 789, 794.
} 
ludzi, jak raczej ich ubóstwu"’76. Z innych pomysłów warto jeszcze podkreślić zachęty do nieskrępowanego handlu zagranicznego i dostosowaniu wielkości pól uprawnych do możliwości samych rolników ${ }^{77}$.

Podobne myśli, w bardziej syntetyczny i odnoszący się bezpośrednio do chłopów sposób, zamieszczone zostały wcześniej w Uwagach nad sposobem wydoskonalenia rolnictwa $w$ Polsce. Owo polepszenie warunków życia i funkcjonowania chłopów zależeć miało od: 1) „oświecenia rolników”, 2) „,zabezpieczenia ich osób i majątku” 3) ,ustanowienia u nich sprawiedliwości”, 4) obmyślenia sposobu zbycia produktów, 5) własnej propinacji, 6) nagradzania najsprawniejszych gospodarzy ${ }^{78}$.

Warto zastanowić się nad tym, jakie kraje i postacie stawiał „Pamiętnik” za wzór w kwestii gospodarowania i sprawy chłopskiej. Wcześniejsze uwagi o preferencji dla rozwiązań związanych z ustanowieniem silnej władzy nie były bezpodstawne w perspektywie reform fizjokratycznych. Wydawać by się mogło, że naturalnie prym powinna wieść Austria czasów Józefa II. Istotnie - wiele miejsca zostało poświęcone kontrowersyjnemu cesarzowi, jednak znaczna liczba stron przypadła na omówienie bardziej czy mniej faktycznych dokonań Fryderyka II i Katarzyny II. O ile pewną słabość Świtkowskiego do „króla-filozofa” łatwiej wytłumaczyć przez jego związki z krajami niemieckimi, to czarowi obietnic Katarzyny II $^{79}$ uległ on we wczesnych pracach redaktorskich podobnie, jak zachodni filozofowie, gdyż ona to „buduje nowe miasta, dawne z swych obalin dźwiga, ludzi zewsząd gromadzi, kolonie z Niemców, Greków (...) zakłada, przez handlu swego rozeznanie może skarby do kraju wprowadzać"80.

Więcej miejsca poświęcono w „Pamiętniku” Fryderykowi II, który choć nie był fizjokratą, to w wielu miejscach upatrywano w nim wzoru. Przede wszystkim jawił się jako wróg handlu gdańskiego i wprowadzenia ceł generalnych w Rzeczpospolitej, czemu jednak przypatrywano się także jako wielkiej efektywności w polityce i relacjach gospodarczych ${ }^{81}$. Podkreślano swoisty interwencjonizm króla pruskiego, który w ciągu jednego tylko roku udzielił przeszło dwa miliony talarów pomocy na zasiewy, gdy trudna sytuacja tego wymagała ${ }^{82}$. Przy względnej słabości Prus, jeśli chodzi o pola uprawne, zasługą Hohenzollerna miała być dbałość

\footnotetext{
76 Ibidem, IX 1787, s. 789.

77 Ibidem, IV 1788, s. 334

78 Ibidem, XII 1784, s. 1141.

79 Katarzyna II miała otrzymać pisma fizjokratów przez Victora de Mirabeau, ucznia i popularyzatora Quesnaya. K. Opałek, op. cit., s. 16.

80 PHP, XII 1784, s. 1141.

81 Podnoszono argument, że wprawdzie potęga Prus nie wynikała z jakiegoś nadzwyczajnego potencjału kraju, ale raczej z jego użycia i przyrostu ludności. Ibidem, III 1785, s. 193.

82 Ibidem, IV 1783, s. 403
} 
o pruskie górnictwo ${ }^{83}$, co także wpisuje się w pomysł godny uwagi fizjokraty. Krytykowano wprawdzie pruski protekcjonizm, ale chwalono niewielkie państwo za przyjmowanie migrantów z innych państw, którzy przynosili ze sobą nowinki techniczne i gospodarskie ${ }^{84}$. Były wreszcie Prusy krajem, gdzie ewidencjonowano liczbę ludności ${ }^{85}$, dbano o logistykę i zapasy, które umożliwiały utrzymanie populacji nawet w czasie wojny czy nieurodzaju ${ }^{86}$.

Wiele, co zrozumiałe, poświęcono Józefowi II, któremu niechętna miała być szlachta - przeciwnie zaś: „gmin, mieszczanie i chłopi niewymownie kochają go" ${ }^{87}$. Nie ma tutaj miejsca dla omawiania wszystkich informacji, warto jednak pokrótce przedstawić powody, dla których był cesarz chwalony w periodyku Świtkowskiego. Przede wszystkim jawił się jako asceta, dążący do racjonalizacji kosztów w administracji, kodyfikacji prawa (by broniło także chłopów), oraz walczący z włóczęgostwem i marnotrawstwem w austriackim Kościele ${ }^{88}$. Prawdziwą zasługą Józefa II miała być jednak walka z konserwatyzmem szlachty węgierskiej, która nie chciała zrezygnować z pańszczyzny i chęć wprowadzenia jedynego podatku, gdyż stan „uciążliwy poddaństwa węgierskiego przeszkadzał do industrii, manufaktur i handlu"89.

Wśród mniejszych aktorów ówczesnej sceny międzynarodowej znajdujemy w „Pamiętniku” informacje dotyczące chłopów w Toskanii, gdzie zniesiono poddaństwo, była własność chłopska lub czynszowa ${ }^{90}$. Wiele ciepłych słów poświęcono Saksonii, gdzie miała się odbywać prawdziwa ,praktyka ekonomiczna” względem uporządkowania gruntów, obsiewania koniczyną tak, by bydło można było hodować zwierzęta przez cały rok: „Idzie o to, żeby z jak najmniejszym kosztem, niewielką pracą, na odłogiem leżących gruntach, a przeto bez najmniejszej ujmy pól zasiewnych lub uszczerbku rodzajów, pomnożyć nawet dwadzieścia razy więcej dobrej paszy" ". I tutaj jednak ,solą w oku” redaktorów periodyku pozostawała pańszczyzna ${ }^{92}$.

Znacznie gorszą prasę miała katolicka Bawaria, gdzie „Pamiętnik” krytykował ,zbytek duchownych” czy fakt, że wiele gruntów pozostało pustych

\footnotetext{
Ibidem, XII 1786, s. 17.

Ibidem, IX 1783, s. 306.

Ibidem, IV 1783, s. 480.

Ibidem, VII 1785, s. 605.

Ibidem, VII 1785, s. 595.

Ibidem, XII 1782, s. 350- 353.

Ibidem, VII 1785, s. 595.

$90 \quad$ Ibidem, VII 1783, s. 62

91 Ibidem, VII 1784, s. 365

92 Ibidem, III 1784, s. 232.
} 
i nieuporządkowanych ${ }^{93}$. Dodatkowym mankamentem była nieprzemyślana akcja osadnicza, gdzie chłopom przeznaczano grunta, których nie było czym obrobić ${ }^{94}$. Negatywne zdanie panowało względem Danii, gdzie ,(...) długo rolnictwo było niedobre, kosztowne i nieużyteczne (jakie zawsze być musi, gdzie jest w zwyczaju poddaństwo)" "95. Podobnie jak Hiszpania i Portugalia, które ślepo miały dawniej zawierzyć potędze kruszców, kraj ten miał jednak wchodzić na drogę rozwoju fizjokratycznego ${ }^{96}$. Wielkie uznanie zyskały za to starania duńskiego ministra Andreasa Petera Bernstorfffa nad gruntami, które przyjął on króla. Miały być słabe i nieurodzajne, on sam chciał jednak pokazać wzór gospodarowania. Do wprowadzonych przez niego reform zaliczyć można: zmniejszenie areału pastwisk, pomiary i porządkowanie gruntów, wydzielenie chłopom pól o regularnych kształtach $\mathrm{z}$ domem chłopskim pośrodku ${ }^{97}$.

\section{„Światli obywatele" i ich reformy}

Analiza sytuacji chłopów w Polsce i rozpatrzenie reform czy udogodnień znanych w innych krajach pozwoliły na formułowanie zaleceń, które bezpośrednio miały tyczyć się życia i społeczno-ekonomicznej roli chłopów w kraju nad Wisłą. Towarzyszyły temu również pionierskie inicjatywy, które realizowano w dobrach prywatnych. Obok pojawiających się postulatów jedynego podatku czy wolnego handlu można wyodrębnić pewne szczegółowe rozwiązania.

Nade wszystko powinien być eliminowany ucisk chłopa jako bezsensowny i sprzeczny naturze. $Z$ tego powodu rząd powinien obrócić swoją uwagę na rolnika i gospodarstwo chłopskie. Podstawą miały być starania właśnie około rolnictwa, skoro manufaktury „nie wszędzie się przyjmują i nie do każdego narodu pasują”, co zdały się potwierdzić losy podskarbiego Antoniego Tyzenhauza ${ }^{98}$. Dla lepszej koordynacji przemian i ich przyspieszenia wzywano do ustanowienia towarzystw rolniczych - ,jeżeli synowie ojczyzny nie zechcą się na wydoskonalenie rolnictwa i pożytkowanie z niego łączyć z jej ojcem, jeżeli gospodarstwo rolnicze tym zechcą prowadzić trybem, którego nas nauczyli ciemni a uporni przodkowie, i przy którym obstawa bydlęcy wieśniaków nałóg: tedy my sami z naszemi mahometańskimi sąsiadami, będziemy tylko w Europie, co w tej mierze nic nieodmieniającymi" ${ }^{99}$. Należało przy tym dbać o dodatni bilans handlowy: „o to się tedy tylko powinno

\footnotetext{
Ibidem, VII 1784, s. 436- 438.

94 Ibidem, VII 1784, s. 439.

95 Ibidem, I 1787, s. 616.

96 Ibidem.

97 Ibidem, I 1784, s. 169.

98 Ibidem, I 1783, s. 19.

99 Ibidem, I 1783, s. 22.
} 
starać prawodawstwo, ażeby kraj tyle tylko wprowadzał zagranicznych produktów, ile może wyprzedać swoich"; by to zapewnić należało albo obniżyć cenę swoich produktów, albo też starać się ograniczyć konsumpcję towarów zagranicznych ${ }^{100}$. Rozwój handlu, gdzie państwo najwięcej miejsca miało poświęcać pobudzaniu handlu wewnętrznego, miał nie tylko „polepszyć wzrost, potęgę i bogactwo kraju”, ale też sprawić, że ,szlachcic, mieszczanin i chłop, dla większej cyrkulacji pieniędzy przychodzi do lepszego bytu, a zaś dobra gruntowe nabierają wyższej ceny"101.

Poza tym musiało zostać zapewnione „zabezpieczenie osób i mienia”- przekonanie, że pan nie ma do nich prawa oprócz przypadku, gdy chłopi chcą się przenieść na inne miejsce ${ }^{102}$. Dopiero nadanie wolności osobistej i bezpieczeństwo w powyższym sensie sprawią, że chłopi „Zwrócą się do rolnictwa i oświecenia”103. Swój wyraz znalazło to nie tylko w pomnikach oświeceniowej myśli w Polsce, jak Kodeks Andrzeja Zamoyskiego ${ }^{104}$, ale też w praktyce ustawodawstwa u kresu I Rzeczpospolitej. Jeszcze „Pamiętnik Polityczno-Historyczny” zdążył pochwalić twórców Konstytucji 3 maja za wzięcie chłopów pod opiekę prawa ${ }^{105}$. Również powołane wówczas Ministerstwo Wewnętrznych Interesów miało na celu ,starania ściągające się do rolnictwa, rybołówstwa, industrii i handlu" - co łączyło czysto fizjokratyczne cele ze specyfiką szlacheckiej Rzeczpospolitej ${ }^{106}$.

Rolą właścicieli ziemskich powinien być za to skup zboża i organizacja prowincjonalnych magazynów ${ }^{107}$. Ponieważ zaś uważano, że pomimo uciążliwości jej sąsiadów, Polska ma duży potencjał handlowy. Chciano rozwijać „ekonomikę handlową," która miała dać teoretyczne podstawy dla zbytu artykułów rolnych ${ }^{108}$. Widziano możliwość ekspansji handlowej polskiego zboża w kierunku Morza Czarnego - zwłaszcza w perspektywie rządów ambasadorskich Ottona Stackelberga w Polsce i współpracy z Katarzyną II $^{109}$. Chłopi powinni być przyuczani do nowinek gospodarskich, ale należało zadbać o wymierzenie, regulację i właściwy

\footnotetext{
100 Ibidem, VI 1784, s. 592.

101 Ibidem, I 1784, s. 7- 9.

102 Ibidem, XII 1784, s. 1145.

103 Ibidem, XII 1784, s. 1147.

104 K. Rogaczewska, Ekonomiczny wymiar polskiego liberalizmu. Od fizjokratyzmu do szkoły krakowskiej, Wrocław 2011, s. 61.

105 PHP V 1791, s. 425.

106 Ibidem, V 1791, s. 445.

107 Ibidem, XII 1784, s. 1149.

108 Ibidem, I 1783, s. 89.

109 Ibidem, II 1786, s. 62. Miało to poparcie także w teorii Quesnaya: „Dla utrzymania dobrej ceny konieczne jest zapewnienie rynków zbytu. Tutaj właśnie decydujące znaczenie ma zniesienie zakazu eksportu. Ale chodzi także o zapewnienie rynku wewnętrznego dla produktów rolnych. Quesnay więc konsekwentnie zwalcza tzw. «luksus w ozdobach», tzn. konsumpcję bardziej kosztownych wyrobów rzemieślniczych, opartych o zagraniczne surowce i jednocześnie zaleca zwiększenie tzw.
} 
podział gruntów: powinni mieć „,małe folwarki, czyli osobno leżące gospodarstwa”, aby wielkość była dostosowana do indywidualnych możliwości uprawy roli ${ }^{110}$.

Osobnym problemem była kwestia istnienia tzw. ludzi luźnych, których fizjokratyzm uważał za potencjalnych mącicieli porządku publicznego i osoby nieproduktywne. Wpływało to na chęć ich zagospodarowania, co czyniono niejako poprzez dwa sposoby: 1) wcielenie do armii, 2) osadzenie w przytułku czy domu poprawczym, gdzie pojawiały się starania o ich reedukację i ponowne przywrócenie zdolności do pracy. Przy zagranicznych inspiracjach pochodzących z Mechelen czy Paryża ${ }^{111}$, podejmowano dyskusję nad żebractwem i włóczęgostwem w Polsce. $\mathrm{Z}$ reguły ograniczano się do projektowania tego typu instytucji w obrębie miast, więc w niewielkim zakresie dotyczyły one chłopów. Postulowano użycie wojska $\mathrm{w}$ trakcie pokoju do prac inżynieryjnych i górniczych, oraz powołanie specjalnego „korpusu górników”"12.

Świtkowski pisał odnośnie rolnictwa, że ,życząc jego u nas wydoskonalenie, a z nim podniesienie obfitości i dostatku publicznego, wystawiam od czasu do czasu wielkie użytecznego rolnictwa okazy (...) i doświadczonych gospodarzy nauki. Ogłaszam co najważniejsze w gospodarstwie wynalazki”"113. Ważne było powołanie się na zakończone sukcesem przykłady reform fizjokratycznych z rodzimego podwórka. Jedną z takich postaci był bez wątpienia ks. Paweł Brzostowski. Janusz Skodlarski w swoim artykule w ten sposób określił pionierski i przełomowy charakter działań duchownego:

„- kupił, a nie odziedziczył majątek, który był bardzo zaniedbany;

- samodzielnie przygotował podstawy prawne i ustrojowe nabytej włości, które czyniły wyłom w ówczesnym ustroju feudalnym;

- opracował podstawy teoretyczne prowadzenia nowoczesnego gospodarstwa rolnego i przez ćwierć wieku wdrażał konsekwentnie reformę włościańską oraz nowe metody uprawy roli;

- uzyskał znaczące efekty ekonomiczne, pomnażając własne dochody, jak również dochody chłopów pawłowskich, podnosząc zarazem ich poziom cywilizacyjny;

- udowodnił praktyce wyższość czynszowej gospodarki chłopskiej nad gospodarką folwarczno-pańszczyźnianą"114.

\footnotetext{
«luksusu konsumpcji», tzn. powiększenie konsumpcji bardziej kosztownych produktów żywnościowych”. J. Zagórski, op. cit., s. 74.

110 PHP, IX 1784, s. 813.

111 Ibidem, V 1783, s. 668; V 1784, s. 486- 487.

112 Ibidem, XII 1787, s. 1051.

113 Ibidem, III 1783, s. 364.

114 J. Skodlarski, Pawet Brzostowski (1739- 1827).Twórca Rzeczpospolitej Pawłowskiej, „Annales. Etyka w życiu gospodarczym” 2009, t. 12, z. 1, s. 70.
} 
Na łamach „Pamiętnika” przedstawione zostały motywacje Brzostowskiego: „Jego dobre i ludzkie serce, nie mogąc znieść biednego stanu nowych swych poddanych, do którego ich doprowadziło bydlęce prawie głupstwo, opuszczenie się i nieporządek, począł myśleć o środkach podźwigających ich, przywróceniu do godności ludzkiej" 115 . Oprócz nadania chłopom wolności, podzielił ich na trzy klasy: 1) wolnych od podatku, 2) czynszowych, 3) pracujących zaprzęgiem ${ }^{116}$.

Jego praca cywilizacyjna polegała również na chęci wprowadzenia zdrowej rywalizacji pomiędzy gospodarzami - dla najlepszych wyznaczał roczne nagrody ${ }^{117}$.

Istotnym elementem, choć często lekceważonym przez ekonomistów, były w czasach oświecenia treści programów szkolnych i działania edukacyjne. Utylitaryzm epoki pozwalał przemycać w nich także nowinki gospodarskie, podnoszące poziom cywilizacyjny ludności ${ }^{118}$. Sam Brzostowski doceniał ten fakt: ufundował szkołę i ustanowił fundusz na utrzymanie nauczyciela, przeciwko „pijaństwu, próżniactwu i złodziejstwu" 119 . Chcąc dać chłopom odwagę i ambicję, miał ksiądz także bardzo przyziemne, wręcz ekonomiczne cele: nauka czytania służyła możliwości zwiększenia wśród ludności czytelnictwa kalendarzy, które zawierały pomocne dla właściwego gospodarowania informacje ${ }^{120}$.

Inną postacią, którą „Pamiętnik” wyniósł na piedestał z uwagi na nowoczesne i odważne gospodarowanie, był Joachim Litawor Chreptowicz, późniejszy wielki kanclerz litewski ${ }^{121}$. Prawdopodobnie jego dotyczyła anonimowa informacja z maja 1784 r.: „Osoba jedna znakomita w Litwie, już była przedtym w dobrach swoich chłopów od poddaństwa uwolniła i szkółki ustanowiła tak, że tam wszyscy czytać umieją" ${ }^{122}$. Jednym z istotniejszych nowości, które wprowadził, były książeczki dla

\footnotetext{
115 PHP IX 1784, s. 857.

116 Ibidem, IX 1784, s. 857.

117 Ibidem, IX 1784, s. 857.

118 Przynajmniej od czasów Oświecenia uznaje się rolę oświaty w historii ludzkiego postępu (choć jasne zdefiniowanie ostatniego pojęcia z reguły prowadzi do kontrowersji). Bardzo istotne znaczenie zyskała ta kwestia w teorii stadiów rozwoju Walta Rostowa. Spośród sześciu stadiów system fizjokratyczny może być klasyfikowany w ramach fazy drugiej (,przygotowanie do startu”). Bardziej istotne, że wśród pięciu podstawowych warunków umożliwiających wzrost gospodarczy, pierwsze miejsce zajęła „minimalna liczba ludzi chcących postępu i przygotowanych do tego rodzaju działań”. Cz. Strzeszewski, Integralny rozwój gospodarczy, Warszawa 1976, s. 17. Bardzo silnie akcentował tę problematykę także sam F. Quesnay: „tylko więc ciemnota mogłaby (...) sprzyjać wprowadzeniu praw sprzecznych ze zwykłym porządkiem prawidłowego i corocznego odtwarzania i podziału bogactw ziemi królestwa. Jeżeli światło rozumu jego rząd oświeca, znikną wszystkie prawa, szkodliwe dla społeczeństwa i dla panującego". F. Quesnay, op. cit., s. 93.

119 PHP, IX 1784, s. 858.

120 Ibidem, IX 1784, s. 859.

121 Zob. K. Tracki, Ostatni kanclerz litewski. Joachim Litawor Chreptowicz w okresie Sejmu Czteroletniego, Wilno 2007.
}

122 PHP, V 1784, s. 505. 
ludu: ustanowione po to, „by byli dobrymi ludźmi” i pomagające odpowiedzieć na pytanie ,czemu nie mogą być dobrymi gospodarzami?" 123.

W innym miejscu szczegółowo zostały opisane należące do Chreptowicza ${ }^{124}$ dobra Szczorse w powiecie nowogródzkim. Jak czytamy w Słowniku geograficznym Królestwa Polskiego: „Włościanie w Szczorsach od dawna odznaczają się wyższym rozwojem umysłowym i dobrobytem, kilka bowiem pokoleń Chreptowiczów dbało o to" ${ }^{25}$. Według „Pamiętnika” Joachim Chreptowicz nakazał przeprowadzić następujące reformy: 1) pomiar gruntów, 2) ogłoszenie wolności osobistej chłopów, 3) zniesienie pańszczyzny, 4) podział gruntów według możliwości gospodarzy i wymiaru czynszów, 5) czynsz dostosowany do jakości gruntu i jego charakteru, 6) folwarki utrzymywane pracą chłopów czynszowych, ale za dodatkową zapłatą ${ }^{126}$.

Wśród innych postaci wymieniony został w „Pamiętniku” również książę August Aleksander Czartoryski ${ }^{127}$, którego pośmiertny biogram został zamieszony w numerze ze stycznia 1783 r. Dzięki niemu ożywiony został w jego dobrach duch „ekonomiki handlowej” wspierającej rolnictwo; on sam wiele uwagi poświęcił porządkowaniu osad i miasteczek ${ }^{128}$.

\section{Warunki bytowe i sposób gospodarowania}

Elementem ekonomicznych postulatów zmian na łamach „Pamiętnika Historyczno- Politycznego" stały się zagadnienia poprawy warunków bytowych i sposobu gospodarowania chłopów. Rolnicy i ich praca, jako istotny element gospodarki, mieli znaleźć się pod opieką państwa w trudnych warunkach codziennego życia. Podstawowym problemem, który skracał chłopskie życie, był niski stan higieny i brak opieki medycznej ${ }^{129}$, które sprzyjały tak niekorzystnej z punktu widzenia

\footnotetext{
123 Ibidem, V 1784, s. 506.

124 Wielu ciekawych informacji o Chreptowiczu dostarcza praca poświęcona Hieronimowi Stroynowskiemu, autorstwa Artura J. Kukuły. Chreptowicz znał francuski i miał się uczyć u samego Quesnaya. Dodatkowo posiadał traktaty francuskich fizjokratów, które wypożyczał. Zalety Joachima Litawora jako myśliciela i krzewiciela nowych poglądów mieli wysławiać Victor de Mirabeau i Dupont de Nemours. Zob. A. J. Kukuła, Hieronim hrabia Stroynowski. Prawnik- ekonomista- fiz.jokrata, Lublin 2009, s. 41- 42.

125 Słownik geograficzny Królestwa Polskiego ..., t. XI, s. 859- 860.

126 PHP, V 1783, s. 531- 532.

127 Zob. W. Konopczyński, August Czartoryski [w:] Polski Słownik Biograficzny, t. IV, s. 272- 275.

128 PHP, I 1783, s. 77- 78.

129 Wielkim problemem była ciągle bardzo wysoka śmiertelność poporodowa kobiet (do 11\%) i niemowląt (do 20\%). P. Guzowski, Badania demograficzne nad rodzinq w okresie staropolskim, [w:] Struktury demograficzne rodziny na ziemiach polskich do połowy XX wieku. Przeglad badań i problemów, red. P. Guzowski, C. Kuklo, Białystok 2014, s. 19.
} 
fizjokratyzmu depopulacji ${ }^{130}$. W Radach obywatela jednego względem zachowania zdrowia, ubranych w literacki kostium opowiadania, opisano tragiczne skutki braku dostępu do lekarza i środków medycznych. Już z tego powodu autor konstatował: „O losie ludzki! Jak jest okropno w naszym narodzie być chłopem, gdy ten stan w ostatnim jest zapomnieniu (...)"131. W zaleceniu autora w każdym powiecie powinien być lekarz i apteka; Komisja Edukacji Narodowej powinna zająć się powołaniem kolegium medycznego, aby mogło kształcić kolejnych medyków ${ }^{132}$. Pozostałe rady sprowadzały się do: 1) upowszechnienia łaźni publicznych, 2) zakazu przechowywania bydła w izbach sypialnych, 3) zakazu spożywania padłego lub chorego bydła, 4) bogatej diety, 5) zbudowania ujścia dla ścieków, 6) nie przetrzymywania zmarłych w izbach podczas gorących dni, 7) walki ze znachorami ${ }^{133}$.

Problem higieny dotyczył też poprawy stanu budynków mieszkalnych, ich bezpieczeństwa i wyposażenia. Zalecano nowe, bardziej ekonomiczne, sposoby ogrzewania domost $\mathrm{w}^{134}$, dbano o polepszenie sposobu budowania chat, by były mniej zawilgocone, ciemne i duszne niż dotychczas ${ }^{135}$. Zachęcano poza tym do budowania domostw czy budynków gospodarskich z kamienia. Wykazywano jego przewagę nad drewnem, które uważano za materiałochłonne, podatne na gnicie i ogieńn ${ }^{136}$. Najlepsze właściwości miał kamień polny, ponieważ pozwalał na: 1) oszczędność czasu, 2) oszczędność drewna, 3) oczyszczenie pól uprawnych, 4) mniejsze nakłady na uprawę ziemi ${ }^{137}$. Ten drobny artykuł rozwinięty został w dziele Świtkowskiego zatytułowanym Architekt wiejski z figurami, gdzie autor jasno stwierdzał, że „materiały budownicze są różne. Nie mieć wiadomości o ich gatunkach, i tych gatunków naturze, wadach, przymiotach i sposobach używania ich jak najoszędniejszego i najużyteczniejszego, bardzo jest szkodliwe. Gdyż to bywa przyczyną wielkiego oszukania, nadaremnych a znacznych wydatków, a częstokroć zawodu całkowitego na budowaniu"138.

W kwestii samego gospodarowania i jego unowocześnień kładziono nacisk na zróżnicowanie produkcji, dostosowanej do wielkości gospodarstwa, siły roboczej,

\footnotetext{
130 Wzrost populacji był względnie dobry, ponieważ zwiększał liczbę rąk do pracy i pozwalał lepiej użytkować grunty.

131 PHP, VII 1785, s. 616.

132 Ibidem, VII 1785, s. 617.

133 Ibidem, VII 1785, s. 622.

134 Ibidem, II 1792, s. 187.

135 Ibidem, XII 1784, s. 1147.

136 Ibidem, VI 1783, s. 679.

137 Ibidem, VI 1783, s. 678.

138 P. Świtkowski, Architekt wiejski z figurami, b.m.w., 1798, s. 23.
} 
rodzaju i jakości gleby ${ }^{139}$. Wykazywano, że hodowla owiec i pozyskiwanie z nich wełny może nieść zysk nie tylko szlachcie, ale i chłopom ${ }^{140}$. Sądzono, że od hodowli tychże zwierząt prosta droga ku zaczątkom manufaktur wełnianych ${ }^{141}$. Starania o pomnożenie pogłowia bydła wiązały się ze wzrostem produkcji koniczyny, pozwalając na wykarmienie zwierząt przez cały $\operatorname{rok}^{142}$. Jak precyzował Świtkowski zalety tejże rośliny w innej publikacji: „Koniczyna czerwona rodzi się na każdym gruncie nawoźnym. (...) Spasa owce, konie, bydło, mleko niezmiernie pomnaża, świniom także, gdy jest młoda, staje się wybornym pastwiskiem, po niej młode prosięta u matek z obfitego pokarmu rosną nadzwyczaj, (...) żywią się pomyślnie kaczki, gęsi, indyki”"143. Dalej następował długi wykład na temat zasiewania, pielęgnacji i zbioru tej rośliny.

Same gospodarstwa chłopskie, dostosowane wielkością do możliwości produkcyjnych mieszkańców, miały posiadać osobny ogród warzywny, które nie tylko ubogacał dietę o takie warzywa, jak ziemniaki, kapusta i groch, ale też plony zapewniały zapas na cięższe czasy ${ }^{144}$.

\section{Zakończenie}

Upadek I Rzeczpospolitej, sam w sobie tragiczny, narzucił polskiej historii pewne schematy, gdzie również na zagadnienia społeczno- ekonomiczne trudno było patrzeć inaczej, niż z punktu widzenia potrzeby rewolucji czy narodowych zrywów. Również na problem chłopski u schyłku XVIII w. zapatrywano się jako na jedną z przyczyn, które nie pozwoliły Polsce ponownie wybić się na niepodległość.

Wydaje się, że jedną z zalet zaprezentowanej pracy może być zerwanie z pewną ahistorycznością: w czasach Stanisława Augusta Poniatowskiego radzono raczej nad tym, jak poprawić byt chłopów, aby mogli oni stymulować wzrost

\footnotetext{
139 Jak pisał A. Turgot: „Wszystkie rodzaje prac przy uprawie roli, w przemyśle, handlu wymagają nakładów. (...) Im więcej uprawa się doskonali, czem szybszem postępuje tempem, tem większych wymaga nakładów. Potrzebne jest bydło, narzędzia rolnicze, budynki dla przechowywania bydła i plonów. Aż do chwili zbiorów trzeba opłacać i żywić liczbę osób odpowiednią do rozmiarów uprawy. Tylko drogą wielkich nakładów otrzymuje się bogate plony, a grunta dają wielki dochód".

A. Turgot, op. cit., s. 33.

140 PHP, III 1784, s. 240.

141 Ibidem, I 1783, s. 137..

142 Ibidem, IV 1788, s. 229, 323. Więcej o dowartościowaniu i roli gospodarki zwierzęcej u Quesnaya: J. Zagórski, op. cit., s. 59- 60. Francuscy myśliciele postrzegali zwierzęta jako „bogactwo ruchome, które poprzedziło nawet uprawę ziemi”. A. Turgot, op. cit., s. 34.

143 P. Świtkowski, Wybór z wiadomości gospodarskich, Warszawa 1787, s. 4-5.

144 PHP, IX 1784, s. 813. Mógł też stanowić pewne zabezpieczenie na wypadek tzw. „klęsk elementarnych" jak mroźna zima z przełomu 1783 i 1784 r. Historia kultury materialnej Polski w zarysie, red. Z. Kamińska, B. Baranowski, t. IV, Wrocław 1978, s. 13.
} 
produkcji i bogactwo kraju. „Pamiętnik” Świtkowskiego doskonale pokazuje, jak wiele aspektów życia i gospodarowania obejmowały te przemiany.

„Zrywa” się tutaj wreszcie z przekonaniem o pewnej rewolucyjności postaci takich, jak ksiądz redaktor analizowanego pisma. Nie był on wcale zwolennikiem jakichś radykalnych reform - wręcz przeciwnie, na łamach jego czasopisma często wypowiadano się o chłopach jako o osobach ciemnych, nieoświeconych i niżej stojących nie tylko od szlachty, ale i mieszczaństwa, z którego wywodził się sam Świtkowski.

Warto też podkreślić, że sposób ukazania koniecznych reform daleko odbiegał tutaj od doktrynerstwa - autorzy bardzo wiele uwagi poświęcili nie tylko analizie lokalnej specyfiki Rzeczpospolitej, ale też porównywali jej problemy z analogicznymi, które rozwiązywano już z lepszym lub gorszym skutkiem w innych państwach.

Nade wszystko jest też analiza ekonomicznych treści „Pamiętnika” potrzebna do tego, aby docenić przepływ idei ekonomicznych do naszego kraju; rola, jaką fizjokratyzm odegrał w torowaniu na naszych ziemiach dróg późniejszym koncepcjom i teoriom ekonomicznym wydaje się być niebagatelna.

\section{The peasants issue depicted in "Pamiętnik Historyczno- Polityczny" by Piotr Świtkowski}

\section{Summary}

Piotr Świtkowski, both a priest and an editor connected with physiocratic ideas, became famous thanks to publishing "Pamiętnik Historyczno-Polityczny" (PHP). On the pages of the magazine, he focused a lot on the issues of the situation of peasants in the Republic of Poland at the end of the 18th century. It did not mean though that he was as radical as historians inspired by Marxism wanted these days. The key to interpretation of the texts related to peasants published in the magazines is the doctrine of physiocracy and an attempt to adapt it to Polish conditions. It was supported not only by the texts that were probably written by Świtkowski, but also by the reprints of the magazines or foreign books. "PHP" analyzed the condition of Polish peasants and discussed many examples or new solutions that came from other countries. Moreover, the initiatives of enlightened Polish reformers were thoroughly discussed. Finally, the living conditions of peasants and their housekeeping preferences were also discussed.

Keywords: journalism of Enlightenment, peasants, physiocracy, Piotr Świtkowski, socioeconomic reforms 


\section{Bibliografia}

Bartkowiak R., Historia myśli ekonomicznej, Warszawa 2003.

Bieniarzówna J., Oczapowski M., Pokłosie fizjokratyzmu, [w:] Physiocracy Yesterday and Today, red. J. Rosicka, Kraków 1996.

Blaszke M., Obraz i naprawa Rzeczpospolitej w myśli społeczno-politycznej Baudeau i le Mercier de la Riviere, Warszawa 2000.

Galbraith J. K., Ekonomia w perspektywie. Krytyka historyczna, Warszawa 1992.

Guzowski P., Badania demograficzne nad rodzina w okresie staropolskim, [w:] Struktury demograficzne rodziny na ziemiach polskich do połowy XX wieku. Przegląd badań i problemów, red. P. Guzowski, C. Kuklo, , Białystok 2014, s. 11-32.

Gide K., Rist K., Historja doktryn ekonomicznych od fizjokratyzmu do czasów najnowszych, t. 1, Warszawa 1920.

Grodek A., Ks. Piotr Świtkowski, statysta polski końca XVIII w., „Rocznik Dziejów Społecznych i Gospodarczych" 1934, R. 3, s. 199-212.

Górski J., Zarys historii ekonomii politycznej, Warszawa 1982.

Historia kultury materialnej Polski w zarysie, red. Z. Kamińska, B. Baranowski, t. IV., Wrocław 1978.

Hombek, Danuta, Prasa i czasopisma polskie XVIII wieku w perspektywie bibliograficznej, Kraków 2001.

Homola-Dzikowska I., „Pamiętnik Historyczno- Polityczny” Piotra Świtkowskiego 178292, Kraków 1960.

Indan-Pykno M., Fizjokratyzm oczyma przedstawicieli polskiej myśli polityczno-prawnej, „Annales UMCS” 2011, nr 2, s. 117-130.

Karpowicz M., Sztuka oświeconego sarmatyzmu, Warszawa 1986.

Konopczyński W., August Czartoryski, [w:] Polski Słownik Biograficzny, t. IV., s. 272- 275.

Kopczyński M., Studia nad rodzina polska w Koronie w XVII-XVIII w., Warszawa 1998.

Korzon T., Ludność Polski w roku 1791, [w:] Odrodzenie w upadku. Wybór pism historycznych, Warszawa 1975.

Kukuła A. J., Hieronim hrabia Stroynowski. Prawnik-ekonomista-fizjokrata, Lublin 2009.

Landes D., Bogactwo i nędza narodów, Warszawa 2015.

Landreth H., Colander D., Historia myśli ekonomicznej, Warszawa 2005.

Lewiński J. S., Twórcy ekonomii politycznej, Lublin 1921.

Lipiński E., Historia polskiej myśli społeczno- ekonomicznej do końca XVIII wieku, Wrocław 1975.

Łojek J., Historia prasy polskiej, t. 1, Warszawa 1976.

Łossowska, Irena, Piotr Świtkowski, [w:] Pisarze polskiego Oświecenia, red. T. Kostkiewiczowa, Z. Goliński, t. 2, Warszawa 1994, s. 305-319.

Malthus T., Prawo ludności, Warszawa 2003. 
O’Connor M., Oświecenie katolickie i Marcin Poczobut SI, [w:] Jezuici a kultura polska, red. L. Grzebień, S. Obirek, Kraków 1993, s. 41-51.

Olszewski H., Zmierczak M., Historia doktryn politycznych i prawnych, Poznań 1993.

Opałek K., Prawo naturalne u polskich fizjokratów, Warszawa 1953.

„Pamiętnik Historyczno-Polityczny przypadków, ustaw, osób, miejsc i pism wiek nasz szczególniej interesujących", Warszawa 1982-1792.

Pietkiewicz Z., Wstęp, [w:] F. Quesnay, Pisma wybrane, Kraków 1928, s. 5-76.

Quesnay F., Pisma wybrane, przeł. B. Pietkiewiczówna, Kraków 1928.

Rogaczewska K., Ekonomiczny wymiar polskiego liberalizmu. Od fizjokratyzmu do szkoły krakowskiej, Wrocław 2011.

Rosicka J., Fizjokratyzm w Polsce [...] Physiocracy Yestrday and Today, red. J. Rosicka, Kraków 1996, s. 157-170.

Rosicka J., Polskie spory o własność. Narodziny nowożytnej myśli ekonomicznej na ziemiach polskich (1765- 1830), Kraków 1984.

Sechelle G., Le docteur Quesnay, Paris 1907.

Sidorowicz, Dorota, „Pamiętnik Historyczno-Polityczny” (1782-1792) w świetle źródet [w:] Krajobrazy przeszłości. Ksiegga ofiarowana doktorowi Adolfowi Juzwence $w$ siedemdziesiata rocznice urodzin, red. M. Dworsatschek, Wrocław 2009, s. 241-246.

Sidorowicz, Dorota, Udziat czasopism Piotra Świtkowskiego w niemiecko- polskim transferze kulturowym doby oświecenia w ujęciu bibliograficznym, [w:] Bibliologia. Problemy badawcze nauk humanistycznych, red. D. Kuźmina, Warszawa 2007, s. 233-243.

Skodlarski J., Pawet Brzostowski (1739-1827). Twórca Rzeczpospolitej Pawłowskiej, „Annales. Etyka w życiu gospodarczym” 2009, t. 12, z. 1, s. 69-78.

Słownik Geograficzny Królestwa Polskiego i innych Krajów Słowiańskich, t. X, Warszawa 1889.

Stankiewicz W., Fizjokratyzm, Warszawa 1982.

Świtkowski P., Architekt wiejski z figurami, b.m.w., 1798.

Świtkowski P., Wybór z wiadomości gospodarskich, Warszawa 1787.

Tracki K., Ostatni kanclerz litewski. Joachim Litawor Chreptowicz w okresie Sejmu Czteroletniego, Wilno 2007.

Turgot A., O tworzeniu i podziale bogactw, przeł. Z.Daszyńska-Golińska, A. Krzyżanowski, Kraków 1919.

Guyot Y., Quesnay e de la physiocratie, Paris 1897.

Weulersse G., Les Physiocrates, Paris 1931.

Wiślicz T., Naród chłopski? Społeczna, religijna i narodowa tożsamość chłopów we wczesno nowożytnej Polsce, [w:] Między barokiem a oświeceniem. Społeczeństwo stanowe, red. S. Achremczyk, S. Kiełbik, Olsztyn 2013. 
Problem chłopski na łamach „Pamiętnika Historyczno- Politycznego” Piotra Świtkowskiego 95

Zagórski J., Ekonomia Franciszka Quesnaya, Warszawa 1963.

Zarys historii gospodarstwa wiejskiego w Polsce, t. 2, red. J. Leskiewicz, Warszawa 1964 